\title{
The Development of the Cystocarp in Rhodymeniales:
}

\author{
II. Delesseriaceae.
}

BY

REGINALD W. PHILLIPS, M.A., B.Sc., Professor of Botany in the University College of North Wales, Bangor.

\section{With Plates XV and XVI.}

T $\mathrm{N}$ a former paper in the Annals of Botany ('97) I published the results of observations on the development of the cystocarp in certain species of the families Bonnemaisoniaceae, Rhodymeniaceae, Sphaerococcaceae, and Ceramiaceae. In still earlier papers ('95 and '96) I had already described the structure of the ceramidia of several species of Rhodomelaceae. But the cohort Rhodymeniales as constituted by Schmitz ('89) contains yet a sixth family, the Delesseriaceae; and in this paper I propose to give the results of an investigation of the structure of the cystocarp in the following species belonging to it :-

Delesseria SANGUINeA, Lamx.

Delesseria alata, Lamx.

Delesseria Hypoglossum, Lamx.

Delesseria RUSCIFOlia, Lamx.

Delesseria sinuosa, Lamx.

Nitophyllum laceratum, Grev.

Nitophyllum Hilliae, Grev.

[Annals of Botany, Vo1. XII. No. XLVI. June, 1898.] 


\section{I74 Phillips.-The Development of the Cystocarp}

\section{DELESSERIA SANGUINEA, Lamx.}

This plant is one of the most conspicuously beautiful of all the Red Seaweeds, and must have been known from early times. It was the Fucus sanguineus of Linnaeus (1767), and on the disintegration of that comprehensive genus became the Delesseria sanguinea of Lamouroux ('13). J. G. Agardh ('51) could not, however, find that its characters harmonized with those of other species of Delesseria, and he therefore adopted for it the generic name Wormskioldia, proposed by Sprengel ('27), but unlike that author, made it the single species of the genus. Later ('76), finding that this name had already been appropriated, Agardh utilized Stackhouse's ('01) generic name Hydrolapathum. More recent writers have assigned it to Delesseria or to Hydrolapathum as they recognized or denied its near relationship to such other typical species of Delesseria as the D. Hypoglossum, D. alata, and D. ruscifolia of Lamouroux. Kützing, by transferring such species as those last named to a genus Hypoglossum, and retaining the designation Delesseria only for $D$. sanguinea and two South Atlantic plants, has shown a certain agreement with Agardh's view of the generic distinction of the Delesseria sanguinea of Lamouroux from the other species of that author. Schmitz ('89), in his ' Uebersicht,' has reverted to the older arrangement of Lamouroux. This course has, as late as last year ('97), called forth a protest from Agardh, who re-asserts his belief in the generic isolation of $D$. sanguinea.

There is, moreover, a wider question at issue among algologists in connexion with this species. While Kützing has separated $D$. sanguinea from other species of Delesseria, he has retained it in the same family with them: Agardh ('76), however, and in this he has been followed by Hauck ('85) and others, has removed it altogether from among Delesseriaceae, and placed it among Rhodymeniaceae. This course he still defends in his latest publication ('97).

It thus appears that there is a difference of opinion, not 
only upon the generic position of $D$. sanguinea, but even upon its ordinal place. I propose to recur to this question later.

The segments of the thallus of $D$. sanguinea simulate the appearance of leaves to a remarkable degree. As, however, Goodenough and Woodward (1795) long ago remarked, 'when attentively considered and compared with others, they appear to be branches growing up into, or dilated into, a thin membrane.' The rudimentary plant consists of a leaf-like lamina, attached by a holdfast. In course of time the winged portion of the thallus disappears, and further growth is provided for by proliferation from the persistent, more or less cylindrical midrib. I believe that in this species a new series of proliferations occurs every year, and that therefore the age of the plant can be accurately measured by counting the joints of the sympodium, of which the plant, from the holdfast to the still growing apex, consists. Among the first proliferations of each recurring period of growth the fertile shoots arise in great numbers (Fig. I). Occasionally the winged portion of an old shoot may persist for some time after the proliferations of a new period have begun to grow, in which case the fertile shoots appear in two rows, right and left of the midrib, on each surface of the leaf-like shoot. These fertile shoots are at first precisely similar in appearance to the corresponding stages of the sterile shoots, but remain small in comparison to the later stages of the latter. The production of reproductive organs, whether tetrasporangia or antheridia or cystocarps, seems to drain the resources of the shoots and to dwarf their vegetative growth. Whilst the sterile shoots of one period may reach many inches or even a foot in length, the tetrasporiferous shoots are hardly more than half an inch long, and the antheridiferous and cystocarpic shoots are even less. I believe, however, that when fertilization fails, procarp-bearing shoots may, and often do, take on again the vigorous apical growth of the sterile shoots, and later become indistinguishable from them.

When, however, fertilization does take place, the female 


\section{I76 Phillips.-The Development of the Cystocarp}

shoots gradually become transformed into the so-called 'pedicellate' cystocarps. These usually occur in considerable numbers along the lateral margins of the midribs, and have much the appearance, when mature, of aggregates of minute berries. By a careful comparison of a series of these structures of varying degrees of maturity, the transformation of the young proliferations into the ripe cystocarps may be made out. With the aid only of such magnification as is afforded by a simple lens the following changes may be observed to occur.

The young shoot in its primary condition is about $\mathrm{I} \mathrm{mm}$. long, and is lanceolate in outline, its width at its widest part being about twice that at its base (Fig. 2). It is perceptibly thicker along the mid-line, as if traversed by a rudimentary midrib. The first appearance of a cystocarp is a slight swelling at the mid-line on one of the surfaces. No dorsiventrality can be detected in these proliferations, and the swelling may arise on either surface. The circular base of this swelling gradually extends to the margins of the lamina, so that the outline is changed from lanceolate to ovate (Fig. 3). Widening still more, the outline might be described as rotund, were it not that a small triangular apical region of the originally lanceolate thallus persists as such (Fig. 4). In elevation the swelling rises so that the vertical diameter is soon as great as the horizontal diameter (Figs. 5, 7), and the swelling is roughly dome-shaped. With the growth of the cystocarp there becomes apparent near the summit of the dome a pore, the margins of which, later, somewhat protrude, transforming the dome into a broad-based urn. The lamina upon which the urn is situated does not remain flat, but, with the progress of growth, becomes somewhat depressed and convex below. The cystocarp, however, never becomes globular, the one-sidedness of the swelling and the existence of the triangular apical flap rendering such a term inappropriate. With the appearance of the cystocarp in the substance of the thallus its apical growth is arrested, and the urn-shaped swelling soon occupies almost the whole of the surface. When 
mature the fructification assumes a dark-red colour, from the dense 'nucleus' of highly-coloured carpospores.

It would appear, therefore, that the so-called stalked cystocarp is more accurately described as a minute flattened branch, upon one of the surfaces of which an urn-shaped cystocarp has arisen.

It is, however, with the minute structure of this cystocarp, and the details of its process of maturation, that I am chiefly concerned. In order to make the following description intelligible, it is necessary to recall the histological structure of the sterile fronds of Delesseria sanguinea and its congeners. This has been the subject of detailed investigations by several observers, and it appears that these species conform rigidly to the law of growth of the Floridean thallus first clearly enunciated by Schmitz ('83). That is to say, the growth is exclusively apical, no transverse division ever occurring in a segment cut off from the apical cell, and no longitudinal division passing through the organic axis of the segment. It is true that Schmitz, returning to this subject later ('92), somewhat limited the application of this law, excluding in particular from its operation the tribe Nitophylleae of the order Delesseriaceae. The tribe Delesserieae, which, standing as it does next to the excluded tribe, it may be assumed that Schmitz examined afresh, was, with the large majority of Florideae, still regarded as falling under the law of exclusive apical growth. With this view I agree, as I have seen nothing in my observations on Delesseriaceae which could be regarded as evidence of intercalary cell-division. Wille ('87) has, it is true, both described and figured intercalary cellformation as occurring in $D$. sanguinea in the axial row of cells during the course of the development of the midrib. As, however, he makes the statement incidentally and without comment, although Schmitz's work had been published some years before, it is probable that the statement was based on a too superficial observation of the thallus. The cells shaded in Figs. I and 3 of Taf. I of his work, are the products of the pericentral cell lying immediately above the central 


\section{I78 Phillips. - The Development of the Cystocarp}

cell. By appropriate means, the much longer, somewhat attenuated axial cell may be seen lying below these cells, and it may be traced, even in the vegetative thallus, in an undivided condition for great distances behind the situation described by Wille. In the young proliferations in which the cystocarps arise, there is no difficulty in tracing the undivided cells of the axial row from base to apex.

I now proceed to describe the structure and arrangement of the procarps in these phylloid branches. For some few cells behind the apical cell, the axial cells, while they give off laterally pericentral cells, which grow out to form the lamellar wing, right and left of the mid-line, do not cut off cells parallel to the flat surface of the thallus. This, however, soon occurs, and immediately following upon the appearance of these pericentral cells above and below, is the appearance of the carpogonial branch. The pericentral cell cuts off, obliquely, right or left posteriorly, a cell, which is the first cell of a 4-celled carpogonial branch. The branch curves round right or left of the pericentral in a plane roughly parallel to the surface, and in such a way that the carpogonium itself is brought forward to a level with the apical part of the pericentral cell which bears the branch, and the trichogyne there passes out obliquely to the surface. The trichogyne is inflated at the extremity, and extends but little beyond the surface. Of the four cells of the carpogonial branch, the first two are each larger than the third and fourth, and the second is considerably larger than the first. As this cell takes up Hoffmann's blue readily, the position of the carpogonial branch can easily be determined even with a low power by its means. The third and fourth cells are small, and are with difficulty distinguishable from one another for some time after the cell-division which gives rise to the carpogonium.

Such a carpogonial branch is borne by the vertically situate pericentral cell of every joint along a considerable length of the fertile branch. They lean however to the right or left of the mid-line in regular alternation. Further, when 
the corresponding pericentral cells on the opposite surface are examined, it is found that they also each give rise to a carpogonial branch which curves round the pericentral cell in the same direction as the carpogonial branch corresponding to it above. These relationships will be most readily realized by means of figures. Figs. 8 and Io show the arrangement of the carpogonial branches as seen from the surface. Fig. 9 gives the appearance of the pairs of carpogonial branches when viewed from the side. The section is supposed to be taken a little to one side of the median line, and the difference in the depth of the shading of the alternate pairs is intended to indicate the slight difference of level. A single thallussegment thus often gives rise to from thirty to forty procarps, the position of all of which can be distinguished in material appropriately stained, and swollen in glycerine. No procarp ever arises elsewhere than in these situations along the midrib.

It does not follow, however, that all these procarps are functional at the same time. They are produced in acropetal succession, and those whose trichogynes protrude at any time are a few in the apical region on each surface. Further back, the midrib becomes stouter by the peripheral growth of the sterile filaments derived from the vertical pair of pericentral cells. Right and left of the middle line, moreover, the lateral pair of pericentral cells and their derivatives give off cells to each surface. By this process the midrib soon becomes six or eight cells thick, and the procarps, which are at the level of the cells nearest to the axis, tend to become more and more immersed. A furrow may at first be detected on the surface on each side of the midrib, joining the points of exit of the trichogynes, where minute pit-like depressions for some time remain. It may well be that the convection of spermatia to the trichogynes is facilitated by the existence of this groove, where they might more readily lodge than on the even surface.

As I have already said, I am inclined to think that some of the procarp-bearing segments grow out into the ordinary 


\section{I80 Phillips. - The Development of the Cystocarp}

vegetative leaf-like shoots when fertilization fails. They resume the vigorous apical growth, and, ceasing to give rise to procarps, attain great lengths. This I infer from the fact that in young branches which are considerably longer than those in the receptive stage, I could still distinguish the remains of procarps in the basal region. Vegetative shoots certainly arise here and there in the fringe of fertile shoots. Such a reversion cannot, however, occur on a large scale; for the young procarp-bearing proliferations may be counted by scores, while the number of vegetative branches on a plant hardly reaches a dozen.

The first indication of the appearance of a cystocarp in these fertile branches is best afforded by staining. One cell of the axial row, the four pericentral cells connected with it, and the adjacent axial cells before and behind, seven cells in all, become so deeply stained by Hoffmann's blue, that this region can then be readily distinguished with the aid of even a hand-lens. I have always found that this stain is taken up with greatest avidity by those cells in which there is great metabolic activity, or a relatively large quantity of protoplasm. Thus, the apical cell, the cells of the carpogonial branch, the auxiliary cell, and carpospores and tetraspores in Florideae, all stain deeply. In the ordinary vegetative cells, it is only the chromatophores and the nucleus that stain readily, the ordinary cytoplasm being hardly tinged in glycerine-material. The deep staining of the cells referred to above indicates that one of the procarps connected with the axial cell, which is the centre of the group, has in all probability become fertilized, and that physiological changes ensue in neighbouring cells, analogous to those which occur in an ovary when the seeds are fertilized. When this stage is reached, however, it may be inferred that a considerable time has already elapsed since the attachment of the spermatium to the trichogyne. In the cases examined, the trichogyne was already so much immersed and obliterated, that it was useless to look for evidence of the presence of the spermatium.

Such deeply stained groups of cells show also a consider- 
able modification of parts, though each is still capable of identification with the earlier condition already described. First, the filaments, other than the carpogonial branch, derived from the same pericentral cell with it, which, when no fertilization takes place, help to form the thickened midrib, now take on a characteristic appearance. These filaments are two in number; one, the larger, springing laterally, and the other, smaller, posteriorly (Figs. I 2 and I 3 ). In all, the tuft which these filaments constitute consists of a score or so of cells. When fertilization of a procarp takes place, these cease to grow further, although all the adjacent filaments in a similar situation take on a more active growth. The cell-walls become greatly thickened and highly refractive, and sharply contrast on this account with the rest of the tissue. The neighbouring filaments growing more vigorously, soon arch over and bury them, without however completely closing the aperture above. The gap thus left is the apical pore of the future cystocarp (Fig. I6). A small portion of the external surface is thus covered in, and may still be distinguished by the foreign substances adhering to it. Both these changes, that in the tuft of filaments which cease to grow, and that in the adjacent filaments which grow the more vigorously, indicate beyond doubt on which side of the thallus fertilization has taken place. I have never found these changes taking place on both sides the thallus, or at more than one spot on the thallus. As it is unlikely that only one procarp becomes fertilized on a branch, it is probable that the demand for nutrition consequent upon the occurrence of the first act of fertilization prevents the formation of a second cystocarp. The case is analogous with that of the ovule of Pinus, for example, where of many possible embryos only one normally matures.

To turn however to the carpogonial branch and the pericentral cell from which it is derived. At the stage above described it is still possible to distinguish the cells of the carpogonial branch, especially since they form a characteristic filament owing to the inequality in the size of the successive cells. The cells, however, have by this time greatly altered 


\section{Phillips. - The Development of the Cystocarp}

in appearance. Instead of readily taking up the stain, they are now the least stained in the whole section. No longer full of dense protoplasm, they are now vacuolated and granular. It is noteworthy, however, that the outline of the carpogonium is larger than before fertilization. The pericentral cell itself, at the earliest stage which I could obtain, had already divided as in Fig. I3, cutting off a large cell towards the apex of the branch. This derived cell is much larger and more conspicuous than the pericentral cell, which is greatly reduced in size by its formation. It is from this cell, undoubtedly, that the gonimoblast-filaments afterwards arise (Fig. I4); and it is highly probable that it is this cell, and not the pericentral cell, which constitutes the auxiliary cell and is fertilized by means of an ooblastema-tube from the carpogonium. Were the pericentral cell itself the auxiliary, it might be fairly argued that it would directly give rise to many gonimoblast-filaments, which it does not. An almost precisely similar case is that of Polysiphonia, in the Rhodomelaceae, where a cell derived from the pericentral cell is now considered to be the auxiliary, since from it, and not from the pericentral cell, the gonimoblast-filaments arise. Other Rhodomelaceae, like Chondria, occur, in which the pericentral cell seems to be the auxiliary. In all Ceramiaceae, it is a cell derived from the cell bearing the carpogonial branch; and this I believe to be the case here. I did not succeed in finding any trace of the ooblastema-tube. It may be noticed, however, that the close contiguity of the carpogonium to the auxiliary cell is favourable for the process of fertilization.

Fig. I4 represents an early stage in the development of gonimoblast-filaments from the auxiliary. The early cells of these filaments have an appearance which I have repeatedly observed. They are disc-like in shape, and seem to be separated by concave walls, fitting one into another like a series of cups. They probably arise in quick succession, pushing forward into the dense mucilage derived from the decadent sterile filaments. The pressure thus produced 
reacts on the pericentral cell, which is pushed back against the central cell, and thus lost sight of. This may possibly account for the statement that the pericentral cell gives rise to the carpospores.

After the stage represented in Fig. I4, I have not been able to find any vestige of the carpogonial branch. It probably atrophies and disappears. The rest of the development of the cystocarp consists chiefly in the luxuriant branching of the gonimoblast-filaments, by which the sporogenous tissue attains considerable bulk in this species. The sterile derivatives of the pericentral cell are pushed off, and may often be seen lying at the peripheral part of the fertile tissue. In the mature condition the contents of the cystocarp exhibit a lobed appearance (Fig. IO), owing probably to the partial separation from one another of the products of a few main branches. Adventitious filaments seem to arise along the larger branches comparatively late in their development (Fig. I5).

The mature cystocarp-bearing branches are considerably longer than the procarp-bearing branches. This is probably due to a general elongation of the cells already formed rather than to continued apical growth. Wille ('87) has shown that in this species there arise from the internal cells of the thallus in the older parts numerous hypha-like cells whose function he considers to be storage. These arise in the basal parts of the cystocarpic branches, and to some extent may account for the greater length.

\section{Delesseria alata, Lamx.}

This plant presents several striking differences of habit from $D$. sanguinea. While it possesses an equally well-marked midrib, the laminar portions are so reduced that the appearance is more that of a winged stem, which is the true morphological equivalence in both cases. In $D$. sanguinea, however, the proliferations of one season do not branch again 


\section{Phillips.-The Development of the Cystocarp}

in the same season; and when the new proliferations arise in the next season, it is exclusively from the persistent midrib. In $D$. alata the plant bifurcates repeatedly in one plane by marginal growth near the apex; and as the apical growth is apparently continuous from one season to another, the plants come to consist of a dichotomously branched thallus of considerable length. In the neighbourhood of the axils between the branches, it also gives rise to dense tufts of adventitious shoots, similar to those which come off the midrib in D. sanguinea. It is on these structures for the most part that the reproductive organs occur; but as far as the production of tetrasporangia and cystocarps is concerned, they also occur, but less commonly, on the surface of the ultimate forkings of the ordinary thallus. Hence it would seem that $D$. sanguinea is a more highly specialized plant than $D$. alata.

The apical growth of the thallus is as pronounced in this species as in the other, and no true intercalary growth occurs throughout its structure. D. alata has been selected by Kny ('86) in his well-known 'Wandtafeln' for illustration of apical growth. Wille ('87), in his figures of the apex, seems to consider that cells of the axial row divide by means of 'horizontal' walls, i.e. by transverse divisions, which is not the case. The so-called 'hyphal' cells which arise from the inner cells some distance behind the apex in $D$. sanguinea occur also in this species. Wille regards their function here as that of conduction, not of storage.

The young axillary proliferations of $D$. alata serve well for the study of the development of the cystocarp, as in the same tuft there may be found varying stages of growth. The cystocarp arises on the midrib some distance behind the apex, and gradually enlarges as a papillar elevation until it can be seen in profile by means of a hand-lens. The mature cystocarp, however, never so completely transforms the appearance of the branchlet as it does in D. sanguinea. This is partly because the cystocarp is not so bulky, and partly because the proliferation is in the end larger than those of D. sanguinea. 
When the cystocarp occurs on the midrib of one of the ultimate forkings of the thallus, it is still smaller in proportion to the size of the thallus. It is only in this condition that it is figured by Harvey ('51).

I have found the arrangement of the procarps to correspond closely to that already described as occurring in $D$. sanguinea The carpogonial branches are 4-celled, and arise on the pericentral cells above and below. They lean to the right and left alternately as in D. sanguinea (Fig. 17). Of the four cells of the branch, the second is here too by far the largest, exceeding in bulk the other three put together. The trichogyne is inflated where it reaches the surface, and protrudes but little.

The next recognizable stage is elucidated by the same selective staining of the axial cell of the fertile joint, and of the six adjacent cells. At this stage the enlarged peripheral sterile derivatives of the pericentral cell are a conspicuous feature, although their appearance is dissimilar from the equivalent structures in $D$. sanguinea. They consist similarly of two branches, but the posterior branch consists of only two cells, and the other branch of four (Fig. 18). These cells are relatively much larger than in $D$. sanguinea, and form a loose aggregate of cells, whose pit-connexion it is not easy to follow.

The carpostome is formed by the over-arching of the surrounding vegetative filaments, though their growth seems to take place in a common mucilage and without any such invagination of the external surface as occurs in $D$. sanguinea. This is doubtless associated with the circumstance that the cystocarp does not attain the large size of that of $D$. sanguinea.

The gonimoblast-filaments arise exclusively from an anterior derivative of the pericentral cell, and are directed forward in the early stage (Figs. 18, 19). There is the same probability that this derivative of the pericentral cell, rather than the pericentral cell itself, is here also the true auxiliary; but the disorganization of the carpogonial branch at this stage 
renders it difficult to find any evidence of conjugation of the carpogonium with either cell.

\section{Delesseria Hypoglossum, Lamx.}

The ordinary vegetative thallus of $D$. Hypoglossum proliferates regularly from the midrib, and there is never any such forking by marginal growth as is found in D. alata. The lateral veins which are so marked a character of the vegetative thallus of $D$. sanguinea, and which occur more obscurely in D. alata, are absent from this species. The segments which bear the reproductive organs are otherwise indistinguishable from the ordinary vegetative segments: hence it would appear that this species is a still less specialized form than D. alata.

The apical growth has long since been accurately described by Naegeli ('47). Owing to the great obliquity of the celldivisions in the lateral pericentral cells, the apical region presents a beautiful appearance which does not occur in any other British species of the genus. I have found this character useful in distinguishing this species from $D$. ruscifolia with which it is sometimes confounded in herbaria.

The hyphal filaments which occur along the midrib in $D$. sanguinea and $D$. alata, and which in the older parts greatly obscure the primitive arrangement of the cells, do not seem to occur in D. Hypoglossum, at any rate at the corresponding stages.

The cystocarp-bearing plants occur only very rarely on the coast of Anglesey. Goodenough and Woodward (1795) contrast the east and west coast of England in this respect. According to these authors, it was only cystocarpic plants that had in their time been found on the coast of Norfolk. I have already ('96) referred to the case of Plumaria elegans. While I could never find female plants of this species on the coast of Anglesey or Carnarvonshire, I found them frequent at Sidmouth. Again, it is well known that Laurencia obtusa and L. pinnatifida rarely occur as cystocarpic plants in British waters. Mr. A. H. Church, who was good enough to send me cystocarpic material of D. Hypoglossum and other 
species from Plymouth, suggests that temperature probably affects the frequency or infrequency of the female plants. Considering that, for the most part, male and female plants among Florideae are, in comparison with the tetrasporic plants, small and apparently depauperized, it may be that the cystocarpic plants are few where the conditions of temperature and illumination are favourable for vegetative development. It is, however, hazardous to generalize in the present state of our knowledge of the natural history of our marine Algae.

Not more than one cystocarp usually arises on D. Hypoglossum in the course of a single branch, though one cystocarp may often be found on each of the many proliferations of a branch which itself bears a cystocarp. The cystocarp is relatively small, and the branch persists after the cystocarp has discharged its spores. The procarps occur along the thallus in the same regular way that has been described for $D$. sanguinea and $D$. alata. On the female plants, at the proper season, every leaf-like branch seems equally to bear carpogonial branches throughout its course, until a cystocarp arises, when the production of procarps generally ceases (Fig. 2,1).

Since the midrib does not thicken to the extent that it does in the species previously described, it is possible to detect the unfertilized carpogonial branches for great distances along the thallus (Fig. 22). It is moreover possible to follow more readily the sequence of events in the young cystocarp. Fig. 22 represents a surface-view of the tuft of gonimoblastfilaments, derived from the auxiliary cell, and the carpogonial branch may still be seen -in an attenuated condition lying alongside the tuft. No signs of a conjugation of the carpogonium and the auxiliary can be seen at this stage; though the incapacity of the cells of the carpogonial branch to any longer absorb the blue stain, which they so readily take up at an earlier stage, suggests that the protoplasmic contents have undergone change. It is fair to add that all the cells of the carpogonial branch behave alike in this respect. 
DELESSERIA RUSCIFOLIA, Lamx.

D. ruscifalia is undoubtedly closely allied to D. Hypoglossum, with which indeed it seems to have been confounded until Turner ('02) pointed out the distinguishing characters. In its dark-red colour $D$. ruscifolia resembles $D$. sanguinea rather than D. Hypoglossum. Its segments are oval or oblong rather than lanceolate, as in D. Hypoglossum; a lateral venation is obscurely traceable also in $D$. ruscifolia, and the cells are much smaller than are those of D. Hypoglossum. There is also a marked difference in the shape of the cystocarp, which in D. Hypoglossum is somewhat flattened, but in $D$. ruscifolia has an elongated neck, and a carpostome with everted rim. As in D. Hypoglossum, each branch of the female plant usually bears a cystocarp, though occasionally, as in Harvey's figure ('51), two may occur on the same midrib.

The procarps occur on the midrib only, but the arrangement is by no means so regular as in the three preceding species. Occasionally no procarp will occur on an axial cell, or two successive joint-cells bear procarps inclined towards the same side, or a procarp will occur on one surface but not at the corresponding situation on the opposite surface. A more important deviation is the rare occurrence of two carpogonial branches arising, one on the right, the other on the left of the same pericentral cell. The cells of the carpogonial branch are also more uniform in this species, though in this respect it resembles $D$. Hypoglossum.

The condition of the young cystocarp figured in Fig. 20 may often be found. It is probable that it represents a pause in the sequence of events between the fertilization of the trichogyne and the production of the gonimoblast-filaments. If so, this lends additional support to the idea that the anterior cell cut off from the pericentral cell is the auxiliary cell, as the halt may be accounted for by the fact that at this stage the conjugation of the carpogonium with the auxiliary cell would occur. As in the other species, it is from this anterior cell alone that the gonimoblast-filaments arise. 


\section{DELESSERIA SINUOSA, Lamx.}

This plant presents so great a general similarity in ap. pearance to $D$. sanguinea, that the collector would readily acquiesce in its inclusion in the same genus with it. As $D$. sanguinea has been appropriately called the 'Dock-leaved' Delesseria, so might this plant be called the 'Oak-leaved' Delesseria. In the remarkable similation of the veined appearance of the leaf of Flowering-plants these two species stand out conspicuously among British Seaweeds.

Kützing ('49), however, constituted for D. simuosa the separate monotypic genus Phycodrys, and although Schmitz in his list of Floridean genera ('89) included the species in Delesseria, he seems later ('92) to have contemplated the possibility of its restoration to the position assigned to it by Kützing.

A brief description of the macroscopic characters will explain this disinclination to include the species in the genus Delesseria. Its branches are traversed by a midrib from which diverge veins into the substance of the distended lamina. This midrib persists when the winged portion disappears, and gives rise by proliferation to the new phylloid branches. More commonly, however, a thallus-segment forks by the more vigorous growth of one of the lobes. Even when a lobe does not develop so as to form a distinct segment, its vein may become a strong secondary rib, from which proliferations may arise as they do from the midrib. Again, $D$. simuosa produces its tetrasporangia in marginal stichidia, like those of some species of Nitophyllum, and not along the sides of the midrib of the vegetative branches, or on special proliferating branches as in species of Delesseria. Further, the cystocarps are scattered in considerable numbers over the marginal region of the thallus-segment away from the midrib, while in Delesseria they usually occur one for each segment, and on the midrib. It is true that in the end the cystocarp of $D$. simuos $a$ is found to be seated on a prominent 


\section{I90 Phillips.- The Development of the Cystocarp}

vein, as shown in Harvey's figure, but this vein arises only after the establishment of the cystocarp.

When the manner of growth of the thallus comes to be considered, $D$. simuosa presents a marked contrast to the species already dealt with. In these there is present at the geometrical apex a single conspicuous cell, which, by its repeated transverse divisions, gives rise to the axial row, the cells of which never divide transversely again, and from which later cells are cut off longitudinally by divisions which do not pass through the organic axis. The pericentral cells thus cut off repeat, in a modified form, the behaviour of the apical cell, and thus the thallus arises. Were it possible to isolate the pericentral cells with their respective products, the whole thallus would resolve itself into a system of branched filaments like a Callithamnion. The growth is apical, in the sense that multiplication of cells takes place at innumerable apices, of which the most important coincides with the geometrical apex, the others lying at the margin and surface, or imbedded in the substance of the thallus. This method of growth Schmitz at first regarded as characteristic of all the Red Seaweeds, exclusive of the Bangiaceae. Naegeli and Schwendener ('67), in their work on the Microscope, had already selected $D$. simuosa and Nitophyllum laceratum as typical cases of growth by intercalation, which they illustrated by figures. Returning to this subject in his later writings, Schmitz ('92) conceded the whole tribe Nitophylleae (including $D$. simuosa) as affording evidence in the structure of the thallus, sooner or later, of intercalary growth. He demurs, however, to the figures of Naegeli and Schwendener, which, he said, left much to be desired. He seemed still to deny that the growth in thickness of the thallus of Nitophyllum is ever due to intercalation, and in particular he refused to acquiesce in Johnson's ('92) suggestion that the callosities of Nitophyllum versicolor afforded an instance of growth by intercalation. With regard to the growth in thickness of the thallus in the neighbourhood of the cystocarps, in both Nitophyllum and D. sinuosa, my own observations convince 
me that it is effected in precisely the way in which it takes place in other families of Florideae, that is to say, by exclusively apical growth. As to the growth in area, where, by inference, it is to be concluded that Schmitz believed growth by intercalation to take place, I have seen no evidence of this either, but do not claim to have given, as yet, adequate attention to the phenomena figured by Naegeli and Schwendener.

From all this, however, it is manifest that in the way in which the thallus of $D$. simuosa arises, it is more akin to Nitophyllum than to the species of Delesseria already described.

When the arrangement of the procarps in $D$. simuosa comes to be considered, the divergence from Delesseria is equally striking. They are found to be distributed in great numbers, without any regularity, in the marginal portions of the thallus. The ultimate ramifications of the veins are obscure lines, traceable only with the aid of the microscope, where a row of axial cells gives off a pericentral cell above and below. Between these veins the thallus is only one cell thick. It does not appear that the procarps in their inception are related in any way to the veins, although a strong vein always arises in connexion with a fertilized procarp. When the procarps arise, an axial cell cuts off a pericentral cell above and below, and from each pericentral cell there springs a 4-celled carpogonial branch, which curves in a characteristic manner before the trichogyne emerges slightly at the corresponding surface (Fig. 29). By the time the carpogonial branches are formed, the pericentral cells from which they originate divide again and give off externally other cells, and a minute swelling in the thallus is the consequence. The trichogynes emerge on the slopes of this swelling. When fertilization fails there is no further development, and great numbers of such unfertilized procarps may be found among the few which are fertilized. The first indication of the development of a procarp into a cystocarp is afforded by the staining properties of the central cell concerned. This extends gradually to the neighbouring axial cells. At this time too 


\section{Phillips.-The Development of the Cystocarp}

the whole area round the spot where the fertilized procarp lies increases in thickness by the cutting off of pericentral cells, in which divisions occur parallel to the surface, giving rise to vertical rows of cells. The peripheral cells, derived from the pericentral cell which bears the fertilized procarp, do not take part in this vigorous growth, but remain in number as at the moment of fertilization. They however enlarge considerably, and assume a characteristic appearance, which is the first indication as to which procarp has been fertilized. The rows of cells surrounding these sterile derivatives arch over them, leaving a central depression which is the carpostome. Pressed by the convergence of the adjacent filaments, the sterile cells, which are five in number, become pyriform, with their pointed ends outwards, and their walls become at the same time thickened and highly refractive. Fig. 27, which represents this stage in Nitophyllum Hilliae, might also serve for $D$. simuosa.

The pericentral cell cuts off a segment, which is the auxiliary cell, and from which later the gonimoblast-filaments arise. The sterile cells are then pushed off, and eventually disappear, supplying in their decadence a copious mucilage.

As will be shown, in these particulars $D$. sinuosa more nearly resembles Nitophyllum than the typical species of Delesseria. The systematic position of the species will be discussed later.

\section{Nitophyllum laceratum, Grev.}

Nitophyllum laceratum may be regarded as the typical species for the genus as established by Greville. There is no percurrent midrib, and the cystocarps are embedded in the substance of the thallus. As it possesses, however, a distinct anastomosing venation in its older parts, and a more obscure venation throughout, it was placed by Kützing ('49) with other species like it in these respects in a genus Cryptopleura, an arrangement, however, which has not found acceptance. 
The procarps are scattered along the margin of the thallus. Fig. 25 represents a procarp in surface-view; its similarity to that of D. sinuosa, as shown in Fig. 29, will be apparent at once. Fig. 24 represents a section through the thallus at a point where the pair of procarps arises.

In the later stages the sterile cells derived from the pericentral form a compact group similar to that shown in Fig. 27.

\section{Nitophyllum Hilliae, Grev.}

Nitophyllum Hilliae is the largest and firmest of all the British species of Nitophyllum. The thallus is for the most part more than one cell thick. Like $N$. laceratum, it has the obscure venation of Kuitzing's genus Cryptopleura. I am indebted to $\mathrm{Mr}$. A. H. Church for fine specimens of this plant from Plymouth.

The procarps are scattered over the thallus as in $N$. laceratum and $D$. simuosa. On closer examination they differ in one important particular from both these species. While each pericentral cell in $D$. simuosa and $N$. laceratum gives rise to a single carpogonial branch, in $N$. Hilliae $\mathrm{I}$ have found that each pericentral cell very regularly gives rise to two such branches. These curve in a crescent on opposite sides of the pericentral cell, and the trichogynes emerge on opposite declivities of the papillar elevation which marks the position of the procarps. As two carpogonial branches emerge on each surface, the swelling marks the site of four carpogonial branches. In this respect $N$. Hilliae is alone among the Delesseriaceae here described, though isolated instances of the same phenomenon occur in D. ruscifolia.

In the genus Ceramium two carpogonial branches also arise regularly from one cell.

Fig. 26 represents a surface view of a pair of carpogonial branches. Fig. 27 represents an early stage of a cystocarp. The group of pyriform sterile cells, which belong to two filaments, have already been referred to. The auxiliary cell has been formed, but has not yet given rise to gonimoblast- 


\section{Phillips.-The Development of the Cystocarp}

filaments. The two unfertilized carpogonial branches of the opposite side of the axis can still be traced. Fig. 28 is an enlarged view of the essential parts of Fig. 27.

When the cystocarp has matured, the papillar outgrowth becomes tuberculated in $N$. Hilliae, owing to uneven growth of the vertical filaments.

I desire now to discuss the mutual relationships of the seven species, the structure of whose cystocarps has been described, and then to consider the affinities of the family to which they belong.

To consider first the four species, $D$. sanguinea, D. alata, D. Hypoglossum, and D. ruscifolia. It is clear that the two plants most closely related are the two last. The leaf-like branches are equally vegetative and reproductive in both, and the branching is exclusively adventitious. In $D$. alata, while the ordinary forkings may give rise to the reproductive organs, there is a marked tendency to produce them exclusively on somewhat specialized adventitious branches. What is only a tendency in $D$. alata has become a fixed condition in $D$. sanguinea. The four species thus form a natural series of which $D$. ruscifolia is perhaps the least specialized, and $D$. sanguinea certainly the most specialized. As has been shown, the structure and the arrangement of the procarps and the development of the cystocarp in $D$. sanguinea present so many features in common with the other three, that there can be no doubt about its inclusion in the same family with them. On account of considerations arising chiefly from a study of the tetrasporiferous segments, Agardh ('76) placed the species as Hydrolapathum sanguineum in the family Rhodymeniaceae. This decision he has recently ('97) discussed in some detail and confirmed. He regards the stichidia or tetrasporiferous branches as unlike those of any other Florideae, finds the closest analogy in the origin and 
arrangement of the spores in the genus Chylocladia, and is convinced from all the characters of the wide separation of Hydrolapathum from Delesseria. On the other hand, it is now clear that in the young condition of the procarp-bearing segment, in the remarkable arrangement of the procarps along the midrib in this segment, in the structure of the carpogonial branch, as well as in the general course of development of the cystocarp, there is the closest agreement between this species and the typical species of Delesseria. And as, from all analogy, the sexual reproductive structure affords the safer criterion in the search for affinities, the similarities here disclosed must be taken to outweigh any dissimilarities appearing in the origin and arrangement of the tetrasporangia. On these grounds, therefore, I cannot but think that Schmitz's contention that Hydrolapathum sanguineum should be restored to the Delesseriaceae, and even to the genus Delesseria, is fully justified.

$D$. sinuosa has had a similarly uncertain position. Schmitz ('92) was latterly inclined to divide the Delesseriaceae into two tribes, the Delesserieae and Nitophylleae, on account of differences in the mode of growth of the thallus. But this division would involve the inclusion of $D$. simuosa among the Nitophylleae, and he therefore suggested the adoption of Kützing's genus Phycodrys for its reception.

This is a course which receives strong support from the study of the development of its cystocarp. In the true Delesserieae the procarps are borne in pairs along the midribs, whereas in $D$. simuosa they are scattered as in Nitophyllum. In the more compact texture of the thallus, moreover, it resembles Nitophyllum. In the existence of a well-marked midrib with diverging veins it resembles species of Delesseria. These characters seem to mark for it a position intermediate between Nitophyllum and Delesseria, and the adoption of Kützing's proposal would meet the case.

With regard to the two species of Nitophyllum, $N$. laceratum comes nearest to $D$. sinuosa. It seems to be premature to suggest the occurrence of two carpogonial branches on each 
pericentral cell in $N$. Hilliae as a ground for the generic separation of this species from Nitophyllum, though, from all analogy, it would seem to indicate a deep-seated difference.

Turning now to the diagnosis of the family Delesseriaceae as given by Schmitz and Hauptfleisch ('97) in Engler and Prantl's 'Pflanzenfamilien,' it would seem to require modification in several particulars.

1. The carpogonial branches are described as 3-or 4-celled. In all the species I examined the carpogonial branch was invariably 4-celled. I never found the number to vary from four cells in the family Rhodomelaceae either. In a recent paper on Grimnellia americana, Harv., a monotypic genus of Delesseriaceae, which seems to stand near to Delesseria, Brannon ('97), has, it is true, described the carpogonial branch as 3-celled, but as he has also stated that it arises directly from a central cell, and not from a pericentral cell, it is just possible that he has missed the real pit-connexion of these cells. Otherwise, Grimnellia differs from all known Delesseriaceae in the origin of the carpogonial branch, as well as from those here described in the number of the cells which constitute it.

2. The carpogonial branches are said to arise singly on an inner cell of the cortex. This does not now cover the case of $N$. Hilliae, where they regularly arise in pairs, nor exceptional cases of D. ruscifolia, where the same thing occurs.

3. The external pericarpial wall is described as formed by a tearing away of the cortical filaments from the middle layer of the thallus. While such a tearing may occur in certain species of Nitophyllum with somewhat flattened cystocarps, it is certainly not general. In Delesseria, the filaments surrounding the cystocarpic cavity become strongly curved, being pressed back at first by the copious mucilage derived from the walls of the sterile derivatives of the pericentral cell, and later by the tuft of spore-producing gonimoblast-filaments. Under this pressure, the cells of the filaments elongate, so as to resemble rows of cylindrical cells, yet the correlation of part to part in the course of growth is 
so gradual, that no rupture of their continuity can be detected.

4. The tearing away of the pericarp is further said to be commonly omitted immediately above the auxiliary cell, where a strand of filaments remains connecting that cell with the pore of the cystocarp above. The strand of cells referred to is doubtless the group of sterile derivatives of the pericentral cell so often described in the foregoing accounts, and if so, it is not a strand of cells but a bushy tuft in $D$. sanguinea, reaching only a part of the distance to the pore, and pushed aside when the gonimoblast-filaments subsequently arise. In the other species of Delesseria the cells are fewer in number, and lie loosely imbedded in a mucilage above the auxiliary cell, still less resembling a strand of cells connecting it with the pore. In D. sinuosa and the species of Nitophyllum the cells are more compact, and the gonimoblast-filaments grow round and over them, justifying the description 'nabelförmig' to this stage in the appearance of the cystocarp. In all cases the pore is the gap left above these cells by the over-arching converging filaments. It is not accurate to describe the sterile group as in any way attached to the pericarp at the pore.

5. As to the formation of a second chamber below, separated from the spore-containing cavity by the middle layer as a kind of diaphragm, a condition figured by Schmitz and Hauptfleisch for $N$. punctatum, I have not been able to find it in the species examined. In the maturer stages of the growth of the cystocarp, the site of the auxiliary cell is the apex of a papilla projecting into the cavity, and while the luxuriant gonimoblast-filaments depress the base of the cavity round about it, they do not, as far as I have been able to see, enter a second cavity on the opposite side of the middle layer.

6. A general fusion of the auxiliary cell with neighbouring cells is described as taking place at the 'placenta.' While such a confluence apparently occurs in some species of Nitophyllum, and is very general in Florideae, it is strikingly 


\section{I98 Phillips.-The Development of the Cystocarp}

absent in the genus Delesseria. Brannon ('97) found moreover that no such fusion occurs in Grinnellia.

7. The pericentral cell is described as playing the part of the auxiliary. I have already given reasons for believing that the auxiliary is an anterior cell cut off from the pericentral cell. An auxiliary cell so derived occurs in most Rhodomelaceae and in all Ceramiaceae.

An interesting feature in the development of the cystocarp in the species here under consideration is the fact that, when the cells adjacent to the central cell in a fertilized procarp become charged with nutriment prior to the formation of the gonimoblast-filaments, they also become multinucleate, as many as eight or ten nuclei at times occurring in one cell. I have found that elsewhere in the thallus of $D$. sanguinea the greatly elongated axial cells contain more than one nucleus.

With regard, finally, to the systematic position of the Delesseriaceae, I have no hesitation, on the ground of the remarkable correspondence in the process of development of the cystocarp, in placing them close to the Rhodomelaceae. There is the same invariably 4-celled carpogonial branch, the auxiliary cell is derived anteriorly from the pericentral cell, and there are always found, in the early cystocarp, two sterile filaments which degenerate later into mucilage. Indeed, the observation of the way in which these sterile filaments arise in Delesseriaceae affords a clue as to their origin in Rhodomelaceae which would otherwise be wanting. In Rhodomelaceae they would seem to be vestigial structures, and the cylindrical Rhodomelaceae would seem to have been derived from forms with a flattened thallus like Delesseriaceae. The two families form one alliance; the simplest forms being represented by Nitophyllum, and the most complex by the polysiphonous Rhodomelaceae. 


\section{BIBLIOGRAPHY.}

1. Agardh, '51 : Sp. Gen. et Ord. Algarum: Vol. ii. pars I ; J. G. Agardh. Lundae, I85I.

2. Agardh, '76 : Sp. Gen. et Ord. Algarum; Vol. iii, Epicrisis; J. G. Agardh. Lipsiae, 1876.

3. Agardh, '97 : Analecta Algologica ; Continuatio iv; J. G. Agardh. Lundae, I 897 .

4. Brannon, '97: The Structure and Development of Grinnellia americana, Harv.; M. A. Brannon; Annals of Botany, vol. xi. Oxford, 1897.

5. Goodenough and Woodward, 1795: Observations on British Fuci; S. Goodenough and T. J. Woodward ; Trans. Linn. Soc., vol. iii. London, I 795 .

6. Harvey, '51 : Phycologia Britannica; W. H. Harvey. London, 1845-5I.

7. Johnson, '92: Callosities on Nitophyllum versicolor; T. Johnson ; Proc. of the R. Dublin Soc., N. S., vol. vii. Dublin, I892.

8. KNy, '86 : Botanische Wandtafeln; L. Kny; Tafel 77. Berlin, I886.

9. KÜTZING, '49: Species Algarum; F. T. Kützing. Lipsiae, I 849 .

10. LAmouroux, '13: Essai sur les genres de la Famille Thallassiophytes nonarticulées. J. V. F. Lamouroux ; Mus. Hist. Nat. Paris, I8I 3.

11. Linnaeus, 1767 : Mantissa Plantarum; C. Linnaeus; Holmiae, I 767 .

12. NAegeli, '45 : Wachsthumsgeschichte von Delesseria Hypoglossum; Carl Naegeli ; Schleiden und Naegeli's Zeitschrift für wissensch. Botanik, Heft 2. Zürich, I 845 .

13. Naegeli und Schwendener, '67: Das Mikroskop; C. Naegeli und S. Schwendener. Leipzig, 1867.

14. Phillips, '95: On the Development of the Cystocarp in Rhodomelaceae; R. W. Phillips ; Annals of Botany, vol. ix. Oxford, I895.

15. Phillips, '96 : On the Development of the Cystocarp in Rhodomelaceae (II). R. W. Phillips; Annals of Botany, vol. x. Oxford, 1896.

16. Phillips, '97: On the Development of the Cystocarp in Rhodymeniales; R. W. Phillips ; Annals of Botany, vol. xi. Oxford, I897.

17. Sсhмiтz, '83: Untersuchungen über die Befruchtung der Florideen; Fr. Schmitz; Sitzungsber. der Berl. Akad. der Wissensch. Berlin, 1883.

18. Sснмiтz, '89: Systematische Uebersicht der bisher bekannten Gattungen der Florideen. Fr. Schmitz; Flora, Heft 5. Marburg, I889.

19. Schmitz, '92 : Kleinere Beiträge zur Kenntniss der Florideen, I, II ; Fr. Schmitz; La Nuova Notarisia, Series III. Padova, I 892.

20. Schmitz und Hauptfleisch, '97 : Delesseriaceae ; Fr. Schmitz und P. Hauptfleisch: Die Natürlichen Pflanzenfamilien; A. Engler und K. Prantl; Lief. I 49-1 50. Leipzig, I897.

21. Sprengel, '27 : Linnaei Systema Vegetabilium, edit. xvi curante C. Sprengel. Göttingen, 1827 .

22. Stackhouse, '01: Nereis Britannica; J. Stackhouse. Bathoniae, i 80I.

23. Turner, '02: Description of four new species of Fucus; Dawson Turner; Trans. Linn. Soc., vol. vi. London, I802.

24. Wille, '87 : Beiträge zur Entwickelungsgesch. der physiol. Gewebesysteme bei einigen Florideen; N. Wille. Halle, 1887 . 


\title{
EXPLANATION OF FIGURES IN PLATES XV AND XVI.
}

\author{
Illustrating Prof. Phillips' paper on the Development of the \\ Cystocarp in Rhodymeniales.
}

The figures are to be regarded as of a semi-diagrammatic character. They were sketched for the most part by means of the camera lucida, but cells lying at different levels have often been figured together, and cells are sometimes left out for the sake of clearness. The cells hatched by means of oblique lines are in all cases those of the carpogonial branch, those hatched by means of horizontal lines in Figs. 20 and 25 are the central cell and its adjacent readily stained cells. The cells with red outlines are those of the sterile filaments derived from the pericentral cell of a fertilized procarp. In Figs. $2 \mathrm{I}, 27,28,30,3^{\mathrm{I}}$, and $3^{2}$, the red colour is also employed for these cells, although the procarps are not yet fertilized. The auxiliary cell and its derivatives are shown with somewhat thickened outlines. In the figures disposed horizontally, the same orientation of parts is preserved throughout, that is to say, the anterior part of the thallus is to the right.

Abbreviations : aux.c., auxiliary cell ; c.c., central cell ; carp., carpogonium ; carp. br., carpogonial branch ; cpst., carpostome; gonbl., gonimoblast-filament ; in. st. br., inferior sterile branch; l. st. br., lateral sterile branch; peric. c., pericentral cell ; tr., trichogyne.

\section{PLATE XV. Figs. I-I 6 .}

\section{Delesseria sanguinea, Lamx.}

Fig. I. An old midrib, giving rise to three sterile branches, and numerous cystocarp-bearing branches in various stages of development. Natural size.

Figs. 2, 3, 4. Views of the flat surface of a thallus-segment upon which a cystocarp is developing. $\times \mathrm{I}_{5}$.

Figs. 5 and 7. Lateral or profile views of two stages in the development of a cystocarp upon such a thallus-segment. $\times \mathrm{I}_{5}$.

Fig. 8. Front view of a procarp-bearing branch, showing the row of axial cells, the pericentral cells derived from them, and the carpogonial branches turned alternately to the right and left. $\times 75$.

Fig. 9. Lateral view of a procarp-bearing branch at the same stage. The axial cells are shown, and the paired pericentral cells of the upper and lower surface, each bearing a carpogonial branch emerging at the corresponding surface. $\quad \times 75$.

Fig. Io. Mature cystocarp-bearing segment, showing the apical flap remaining, and the lobing of the contents of the cystocarp. $x$ Io.

Fig. II. Magnified view of a segment at the same stage, and of the same view as in Fig. 8. The eighth segment behind the apical cell has an immature procarp, afterwards the carpogonial branches are fully developed. $\times 600$. 
Fig. I 2. A single procarp (unfertilized) showing the relation of the sterile filaments (red) to the carpogonial branch. $\times 900$.

Fig. I3. A single procarp at a stage subsequent to fertilization. The carpogonial branch is still present but by no means so conspicuous relatively as in the figure. The auxiliary cell has been cut off from the anterior part of the pericentral cell. The sterile filaments begin to undergo mucilaginous degeneration. $\times 500$.

Fig. I4. Median vertical section of a segment about the stage shown in Fig. 7 . The carpogonial branch is still visible, but only with difficulty traceable in a section. The auxiliary cell has developed a minute tuft of gonimoblast-filaments. The section is drawn through the carpostome, and the invaginated portion of the external surface is shown below. $\times 300$.

Fig. I5. A strong gonimoblast-filament giving rise to an apparently adventitious lateral branch. $\times 300$.

Fig. I6. Lateral view of the apical region of a procarp-bearing segment. Magnification inferior to that of Fig. II. $\times 35^{\circ}$.

\section{PLATE XVI.}

\section{Delesseria alata, Lamx. Figs. I7, I8, I9.}

Fig. I7. Vertical section through a procarp-bearing segment close behind the apex. The pair of procarps corresponding to every axial cell is shown. The first and third pair of carpogonial branches are on the hither side of their pericentral cells, and the second on the farther side. $\times 600$.

Fig. 18. A fertilized procarp in vertical section. The auxiliary cell has already divided once. The carpogonial branch is not shown. $\times 400$.

Fig. 19. A stage later. The auxiliary has given rise to a tuft of filaments by repeated branching. $\times 400$.

\section{Delesseria ruscifolia, Lamx. Fig. 20.}

Fig. 20. Surface view of a fertilized procarp. The cells hatched by horizontal lines are three cells of the axial row and two lateral pericentral cells. These five cells stain readily. The carpogonial branch is distinctly visible. The pericentral cell has divided off (anteriorly) an auxiliary cell. The sterile derivatives of the pericentral cell coloured red. The other cells are superficial. $\times 75^{\circ}$.

Delesseria Hypoglossum, Lamx. Figs. 2 1, 22, 23.

Fig. 2I. Two cells of the axial row close to the apex with its derivative pericentral cells. From each of these are derived sterile derivatives and a carpogonial branch. $\times 1200$.

Fig. 22. Three axial cells far behind the apex. The carpogonial branches immersed in the tissue of the midrib and atrophying. $\times 300$.

Fig. 23. A view from the surface, corresponding to that shown in Fig. 20, for D. ruscifolia. The auxiliary has grown out into gonimoblast-filaments. The sterile cells are omitted. $\times 75^{\circ}$.

\section{Nitophyllum laceratum, Grev. Figs. 24, 25 .}

Fig. 24. Vertical section of the thallus, showing a pair of carpogonial branches, arising from the pericentral cells of one axial cell. $\times 75^{\circ}$.

Fig. 25. Surface view of a procarp. The axial cell is not shown. $\times 750$. 


\section{Phillips.-The Cystocarp in Rhodymeniales.}

Nitophyllum Hilliae, Grev. Figs. 26, 27, 28.

Fig. 26. An axial cell with its pericentral cell. Surface view. Two carpogonial branches arise from the one pericentral cell. The sterile derivatives are not shown.

Fig. 27. Vertical section of a stage later, when the auxiliary cell has been cut off. The sterile filaments are a group of cells with the pointed apices directed towards the carpostome. The carpogonial branch may still be traced. Two others on the opposite side the axis are faintly traceable. $\times 180$.

Fig. 28. Enlarged view of the central region of Fig. $27 . \quad \times 500$.

Fig. 29. Delesseria simuosa, Lamx. Surface view of a procarp, to show its similarity to $N$. laceratum (Fig. 26 ).

Fig. 30. Rhodomela subfusca.-Products of the pericentral cell at the stage of fertilization diagrammatically represented.

Fig. 3I. Similar diagram for D.alata, D. ruscifolia, D. Hypoglossum, D. sinuosa, $N$. laceratum, $N$. Hilliae.

Fig. 32. Similar diagram for $D$. sanguinea, to which Dasya coccinea approximates. 


\section{$2 \mathrm{BHL}$ Biodiversity Heritage Library}

Phillips, Reginald W. 1898. "The development of the cystocarp in Rhodymeniales: II. Delesseriaceae." Annals of botany 12, 173-202. https://doi.org/10.1093/oxfordjournals.aob.a088690.

View This Item Online: https://www.biodiversitylibrary.org/item/233102

DOI: https://doi.org/10.1093/oxfordjournals.aob.a088690

Permalink: https://www.biodiversitylibrary.org/partpdf/318502

\section{Holding Institution}

Smithsonian Libraries

\section{Sponsored by}

Biodiversity Heritage Library

\section{Copyright \& Reuse}

Copyright Status: Not in copyright. The BHL knows of no copyright restrictions on this item.

This document was created from content at the Biodiversity Heritage Library, the world's largest open access digital library for biodiversity literature and archives. Visit BHL at https://www.biodiversitylibrary.org. 